\title{
The effect of entrepreneurial orientation and technology orientation on market orientation with education as moderation variable
}

\author{
Salim Al Idrus ${ }^{\mathrm{a}^{*}}$, Abdussakir ${ }^{\mathrm{a}}$ and Muhammad Djakfar ${ }^{\mathrm{a}}$
}

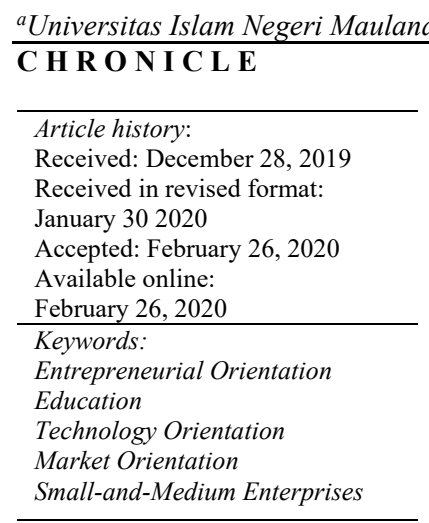
\begin{abstract}
A B S T R A C T
This research is aimed to disclose the influence of entrepreneurial orientation and technology orientation on market orientation with education as a moderation variable. Referring to the assumption of research approach, the study uses quantitative approach and causal relationship across variables is examined with SEM-PLS. The object of research includes Small-and-Medium Enterprises in East Java, Indonesia. Sampling method is simple random sampling with Malhotra technique. After applying it to research population, the obtained sample is 150 Small-and-Medium Enterprises. Data are collected with questionnaire. Responses are analyzed using statistic program of Smart-PLS version 3.2.7. Some empirical findings are obtained: (1) The increase of entrepreneurial orientation and technology orientation is going along with the increase of market orientation; (2) Education strengthens the impact of entrepreneurial orientation on market orientation; and (3) Education can reduce the influence of technology orientation on market orientation.
\end{abstract}

C 2020 by the authors; licensee Growing Science, Canada

\section{Introduction}

Some business experts view Small-and-Medium Enterprises (SMEs) as business unit with great contribution to economic growth due to their capacity in delivering products and services optimally (Rekarti \& Doktoralina, 2017, p. 614; Sanjo \& Ibrahim, 2017, pp. 67-68; Tambunan, 2017, p. 89). Small-and-Medium Enterprises also provide jobs for citizens. Most importantly, their marketing has been organized in such a way to capture the momentum of ASEAN Economic Society that covers Indonesia and Southeast Asian regions. The development of Small-and-Medium Enterprises in Indonesia is encountered with a problem of lack of capacity in understanding market change and in offering the proper outputs to consumers (Rekarti \& Doktoralina, 2017, p. 614). Indeed, Indonesian SMEs are frequently facing problems related with marketing, market orientation and product competition (Hadiyati, 2015, p. 128). Marketing is considered as the most vital element for SMEs to survive in business competition (Omsa, Ridwan, \& Jayadi, 2017, p. 71). One reason why SMEs are lacking of market orientation is human resource. Both manager and workers of SMEs tend to lack of innovation (Golibjon, 2016, p.2) and of creativity (Rahadi, 2016, p. 50). Consequently, entrepreneurship values applied at SMEs become less efficient (Sidik, 2012, p. 378). Small-and-Medium Enterprises with high entrepreneurial orientation give more focuses on market orientation. They capture any opportunities that allow them to send their products to relatively new market, dare to shift to new products or services to adapt with demand contingencies in the future, and build more courage to confront the competitors (Neneh \& Zyl, 2017, p. 173). If Small-and-Medium Enterprises apply entrepreneurial orientation as their entrepreneurial strategy and put it into their strategic planning, then their business may grow significantly (Guzman, Serna, \& Castro, 2017, p. 99). Moreover, other factor that causes why market orientation of Indonesian SMEs is low is that SMEs' products are failed to compete with products from larger companies or outnumbered by Chinese-imported products.

* Corresponding author.

E-mail address: salim.alaydrus@manajemen.uin-malang.ac.id (S. Al Idrus) 
This failure is associated with the use of low technology in SMEs' production process (Sudaryo \& Permatasari, 2017, p. 102). Small-and-Medium Enterprises are still less integrated with up-to-date technology, especially concerning with information technology (Dachlan et al., 2016, p. 319) or the latest technology in production process (Munizu, Sumardi, \& Armayah, 2016, pp. 121-122). Being oriented toward the latest technology allows SMEs to satisfy consumer demands that always change with technology development and as time goes. Small-and-Medium Enterprises with technology orientation are usually producing more profits and more efficient in managing their business unit (Kasim \& Altinay, 2016, p. 122). Besides, entrepreneurial orientation and technology orientation, another aspect affecting market orientation is education level of manager and workers of SMEs (Rupčić, 2016, p. 246). It is not surprising fact that SMEs often disregard education level during recruitment and hiring process, and only absorb workers in order to reduce unemployment. Educated workers will increase the possibility of SMEs to be more successful (Hosseininia \& Ramezani, 2016, p. 12). Educated workers also help SMEs translate consumer demands into products. If Small-and-Medium Enterprises fulfil consumer demands satisfyingly, then it is said that they successfully build market orientation and this market orientation enables them to increase profitability. Referring to phenomena explained in previous paragraphs, it can be said that some factors are affecting market orientation of Small-and-Medium Enterprises in Indonesia. These factors are entrepreneurial orientation, technology orientation, and education. Research attempts to provide empirical explanations about the effect entrepreneurial orientation and technology orientation on market orientation in Small-and-Medium Enterprises in Indonesia with education as moderation variable.

\section{Literature Review}

\subsection{Education}

Education is one critical factor for the success of business unit like Small-and-Medium Enterprises (SMEs) (Othman et al., 2016, p. 79). Education is a force that drives workers to think critically and motivates them to develop business. Education also guides SMEs' workers and entrepreneurs to achieve goals and visions of the business that will escort them to the success (Othman et al., 2016, pp. 79-80). High education level is viewed as main factor for the development of socio-economic and human resource (Hosseininia \& Ramezani, 2016, p. 12; Kim, 2017, p. 45). Educated workers can apply what they learn from school at workplace. If SMEs have workers who are able to apply organizational learning, then market orientation can be achieved easily. The reason is that highly educated workers tend to apply organizational learning with a purpose to improve SME's performance (Thomas et al., 2017, p. 3).

\subsection{Entrepreneurial Orientation}

Entrepreneurial orientation is a business unit practice to implement entrepreneurship domain for the success of business unit (Duru, Ehidiamhen, \& Chijioke, 2018, p. 2). Entrepreneurial orientation is the stepping stone for SMEs before they develop market orientation. This entrepreneurial orientation is built through developing new products, innovating products, and coping with market competitors (Kozubíková, Sopková, Krajčík, \& Tyll, 2017, p. 209). Dimensions that constitute entrepreneurial orientation are innovation, risk-taking and proactive (Kozubíková et al., 2017, p. 209; Platin \& Ergun, 2017, p. 79). Business performance will be optimum if SMEs are innovating with their business activity (Susanto \& Wasito, 2017, p. 282). Both innovation and creative ideas are needed if SMEs desire to be more competitive. Indeed, if all these attributes are executed, it is certainty that SMEs will be rewarded with entrepreneurial orientation. The consequence of having entrepreneurial orientation is that SMEs can build market orientation easily (Hussain, Rahman, \& Shah, 2016, pp. 396-397).

\subsection{Technology Orientation}

Companies with technology orientation are always reserving their resource to apply the newly latest technology to develop new process, new product and new service, which is targeted to produce higher performance (Nakola, Tarus, Buigut, \& Kipchirchir, 2015, p. 340). Technology orientation helps companies obtain substantial technological background, which they can use it to produce new solution in responding consumer demands (Lo, Wang, Wah, \& Ramayah, 2016, pp. 374; 340). The nowadays consumers tend to select products and services that preserve technological advancement. Invention and creativity in adopting technology may guide the companies to decide what strategic implementation that they should take. Small-andMedium Enterprises that focus on the latest technology can offer ultimate products that are hardly for competitors to imitate. Therefore, technology orientation can increase the success and profitability of new products (Lo et al., 2016, p. 375).

\subsection{Market Orientation}

Market orientation is when business unit can identify market and build market-driven capacity (Dursun \& Kilic, 2017, p. 2). Market orientation is an organizational culture that can be effectively producing a business attitude that respects consumer value and produces sustainable business (Kohli \& Jawarski, 1990; Wilson, Perepelkin, Zhang, \& Vachon, 2014, p. 36). Market orientation is viewed as critical element in dealing with more intensive competition and therefore, performance of business unit, like SMEs, is always affected by market orientation (Kalmuk \& Acar, 2015, p. 166; Zainul, Astuti, Arifin, \& Utami, 2016, p. 3). Indicators that shape market orientation include: (1) focusing on customer interest; (2) monitoring competitor movement, and (3) being responsive to customer and competitor interests to invest satisfaction to become loyalty (Day, 1998, p. 8; Dursun \& Kilic, 2017, p. 2). Market orientation is considered important because it requires the company to collect relevant information, such as what the company wants, what the customers want, what the competitors do, and how the market 
fluctuates in aligning with social, economic and environmental issues (Glavas \& Mish, 2015, p. 636). Any information collected for building market orientation are important materials to deliver excellence value to customer (Slater \& Narver, 1995) because market orientation affects the development of business environment (Segarra, Peiro, \& Cervello, 2015, p. 1471). Small-and-Medium Enterprises that have market orientation will be more responsive and anticipative to all demands and desires of the consumers either in current or future days (Kiessling, Isaksson, \& Yasar, 2016, p. 271).

\section{Method}

\subsection{Design and Type of Research}

Based on the classification of research design, this research is classified into quantitative type. Quantitative research is a research that explains causal relationship among variables. The analysis technique is Structural Equation Modeling-Partial Least Squares (SEM-PLS). Two kinds of variable are examined in this research. One of them is variable that its value cannot be measured or known quantitatively (latent), or construct that becomes variable and has quantitative value at certain measuring unit. Variable in such kind is known as unobserved variable. The other kind is the indicator of variable that is used to measure latent variable or unobserved variable. This measurer is called as observed variable. Variable that cannot be measured directly (latent) comprises exogenous and endogenous latent variables. In relation with this research, there are three exogenous latent variables, namely: (1) Entrepreneurial Orientation (EO); (2) Education (E); and (3) Technology Orientation (TO). Meanwhile, endogenous latent variable is Market Orientation (MO). Hypothesis frame design is visualized in the following.

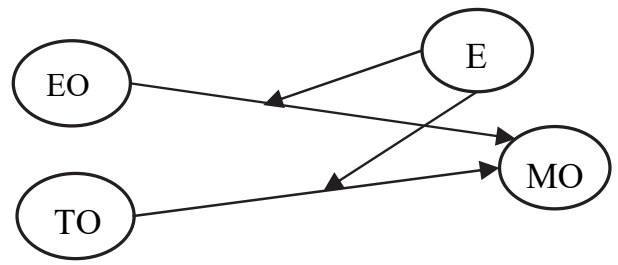

Fig. 1. Hypothesis frame model

\subsection{Target Population and Sample Unit}

Population target of this research is the entrepreneurs of Small-and-Medium Enterprises in East Java. Sample is taken with simple random sampling where each sample of SMEs is simply taken from the predetermined region, precisely where SMEs are located. Sample size is determined using Malhotra Technique (Malhotra, Nunan, \& Birks, 2017, p. 712). This technique takes the number of samples at least five to ten times the number of indicator of SMEs population in East Java. Reason why this technique is used is that the actual number of target population is unknown, and that number of SMEs is always growing and many of them are not registered (not yet updated) in the Department of Cooperative and SMEs for East Java Province. Early assumption for this issue is that one indicator is represented by one item in questionnaire. If there are twelve indicators, and if these indicators are multiplied by 10 , then the minimal number of samples would be 120 SMEs entrepreneurs. Total questionnaire distributed to respondents is 170 sheets, while questionnaire returned to researcher is 150 sheets. Therefore, the response rate is $88.24 \%$ and all the returned questionnaires are used for data analysis.

\subsection{Research Instrument}

The instrument of research is closed questionnaire with four-interval Likert Scale. Scoring system arranges respondents' answers into four answer alternatives. The blueprint of research instrument is displayed in Table 1 as follows.

Table 1

Instrument grids

\begin{tabular}{|c|c|c|c|}
\hline No. & Variable & Instrument & Indicator \\
\hline 1. & $\begin{array}{l}\text { Education (E) } \\
\text { (Thomas et al., 2017) }\end{array}$ & Questionnaire & Education level \\
\hline 2. & $\begin{array}{l}\text { Entrepreneurial Orientation (EO) } \\
\text { (Kozubíková et al., 2017; Platin \& Ergun, 2017) }\end{array}$ & Questionnaire & $\begin{array}{l}\text { a. Innovation on new product and new strategy } \\
\text { b. Proactivity in solving business issue } \\
\text { c. Dare to take risk }\end{array}$ \\
\hline 3. & $\begin{array}{l}\text { Technology Orientation (TO) } \\
\text { (Lo et al., 2016; Nakola et al., 2015) }\end{array}$ & Questionnaire & $\begin{array}{l}\text { a. Technology novelty } \\
\text { b. Business innovation }\end{array}$ \\
\hline 4. & $\begin{array}{l}\text { Market Orientation (MO) } \\
\text { (Day, 1998; Kohli \& Jawarski, 1990; Wilson et al., 2014; } \\
\text { Protcko \& Dornberger, 2014; Ferraresi et al., 2012) }\end{array}$ & Questionnaire & $\begin{array}{l}\text { a. Be active in taking intelligence from customers } \\
\text { b. Be active in taking intelligence from competi- } \\
\text { tors } \\
\text { c. Distribute information derived from market in- } \\
\text { telligence } \\
\text { d. Keep abreast of market development } \\
\text { e. Be responsive to customer complaint } \\
\text { f. Be responsive to what competitors do }\end{array}$ \\
\hline
\end{tabular}




\subsection{Data Collection Technique}

For the interest of research, researcher collects the data using survey instrument, which more popularly regarded as questionnaire.

\subsection{Data Description}

Data analysis and hypothesis test are done using SEM-PLS. Such analysis method is aimed to conduct a testing whether independent variable (not affected by other variable, or called as exogenous variable) affects dependent variable (affected by other variable, or called as endogenous variable). Data analysis process is facilitated by computer program named Smart-PLS Version 3.2.7. This research decides to use Partial Least Square (PLS) for data analysis because research attempts to examine the contribution of data to the causal relationship of latent variables. Two considerations are interposed for the selection for PLS. One of them is because this research uses four latent variables, while the other is because the sample is in small category. Path diagram of research model is visualized in Fig. 2.

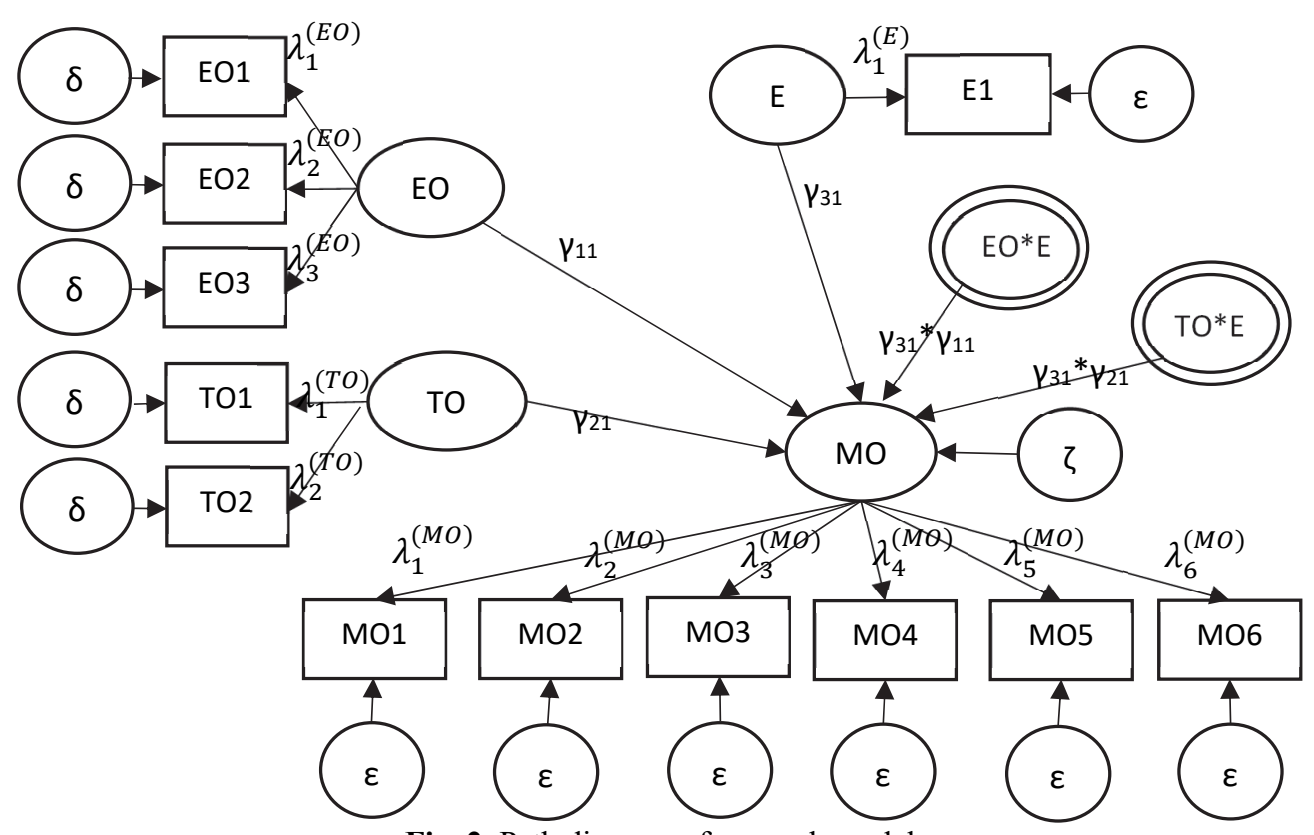

Fig. 2. Path diagram of research model

Hypothesis test in PLS method is done using resampling bootstrap (Jaya \& Sumertajaya, 2008, p. 126). Significance level test is done to understand the comparison between t-statistic and t-table values. If t-statistic (t-count) value is $\geq \mathrm{t}$-table ( $\geq 1.96$ ), or when the output of Smart-PLS shows P-value $\leq 0.05$, then the decision is rejecting $\mathrm{H}_{0}$ and accepting $\mathrm{H}_{\mathrm{a}}$ (Jogiyanto, 2011, pp. 72-73). In other words, exogenous variables (entrepreneurial orientation and technology orientation) are directly affecting endogenous variable (market orientation), which also signifies that there is obvious and significant effect of independent variables on dependent variable. There is moderation effect from Education (E) on Market Orientation (MO). This moderation effect is described through the influence of exogenous variables, namely Entrepreneurial Orientation (EO) and Technology Orientation (TO), on endogenous variable, that is, Market Orientation (MO) through moderation of Education (E). This moderation effect is tested using Baron and Kenney's Norm, which says that moderation effect can be tested only if the direct effect (direct effect of exogenous variable on endogenous variable) is obvious and significant (Jogiyanto, 2011, p. 105). If the Norm is not fulfilled, moderation effect test cannot be proceeded.

\section{Results}

Hypothesis test is conducted after the implementation of Goodness of Fit test on Outer Model and Inner Model (Jogiyanto, 2011, pp. 72-73). The process of Goodness of Fit test is assisted by computer program of Smart-PLS version 3.2.7, and the results are presented in figures and tables in the following sections.

\subsection{Goodness of Fit Test on Outer Model}

Result of Goodness of Fit test on Outer Model consists of few components, such as: (1) convergent validity, which is determined based on value of (a) correlation across construct indicators (factor loading rate) and (b) AVE; (2) discriminant validity, which is determined based on cross loading rate; and (3) reliability, which is obtained through composite reliability test. Results of convergent validity test for factor loading rate are illustrated in Fig. 3. 


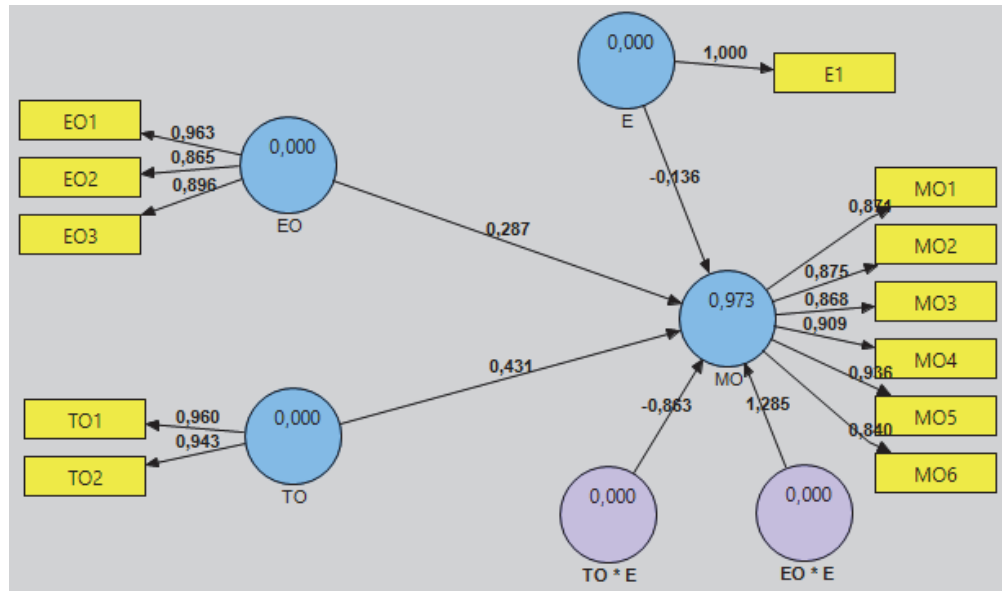

Fig. 3. Result of factor loading calculation

(Source: Result of Analysis with Smart-PLS Program at significance level of 5\%)

Results of convergent validity test for AVE are shown in Table 2 as follows:

Table 2

Results of AVE recapitulation

\begin{tabular}{ccc}
\hline Latent Variable & AVE \\
\hline E & 1.000000 & 0.825773 \\
EO & 0.780975 \\
TO & 0.904997 \\
\hline
\end{tabular}

(Source: Result of Analysis with Smart-PLS Program at significance level of 5\%)

Results of discriminant validity for cross loading rate are presented in Table 3 . Reliability test on variables is conducted by determining composite reliability, and the result is indicated in Table 4.

Table 3

Results of cross loading rate recapitulation

\begin{tabular}{|c|c|c|c|c|}
\hline Cross Loading Rate & Education & Enterpreneurship Orientation & Technology Orientation & Market Orientation \\
\hline E1 & 1.000000 & 0.89569 & 0.898367 & 0.928774 \\
\hline EO.1 & 0.867899 & 0.962618 & 0.90138 & 0.931087 \\
\hline EO.2 & 0.711193 & 0.864862 & 0.807571 & 0.840533 \\
\hline EO.3 & 0.857043 & 0.895936 & 0.832312 & 0.880427 \\
\hline TO.1 & 0.922206 & 0.965408 & 0.959958 & 0.978149 \\
\hline TO.2 & 0.775492 & 0.79663 & 0.94259 & 0.820543 \\
\hline MO.1 & 0.731835 & 0.86604 & 0.847334 & 0.870818 \\
\hline MO.2 & 0.856735 & 0.838849 & 0.804077 & 0.875075 \\
\hline MO.3 & 0.855527 & 0.816597 & 0.760298 & 0.868378 \\
\hline MO.4 & 0.874967 & 0.872877 & 0.952367 & 0.909315 \\
\hline MO.5 & 0.905378 & 0.918124 & 0.887382 & 0.935577 \\
\hline MO.6 & 0.688354 & 0.848198 & 0.78446 & 0.839959 \\
\hline
\end{tabular}

(Source: Result of Analysis with Smart-PLS Program at significance level $(\alpha)$ of $5 \%$ )

Table 4

Summary of composite reliability calculation

\begin{tabular}{ccc}
\hline Latent Variable & Composite Reliability \\
\hline E & 1.000000 \\
EO & 0.934169 \\
EO E & 0.996046 \\
TO & 0.955293 \\
TO $*$ & 0.950126 \\
\hline
\end{tabular}

(Source: Result of Analysis with Smart-PLS Program at significance level $(\alpha)$ of $5 \%$ )

\subsection{Result of Goodness of Fit Test on Inner Model}

Result of Goodness of Fit test on Inner Model is indicated by R-Square value $\left(\mathrm{R}^{2}\right)$. The obtained $\mathrm{R}^{2}$ value from the test is shown in Table 5. 
Table 5

Recapitulation of $\mathrm{R}^{2}$

\begin{tabular}{cl}
\hline Latent Variable & R Square \\
\hline MO & 0.973323 \\
\hline
\end{tabular}

(Source: Result of Analysis with Smart-PLS Program at significance level $(\alpha)$ of $5 \%$ )

Complete recapitulation of results of Goodness of Fit test are explained in Table 6. Referring to Table 5, it can be said that in general, all criteria of Goodness of Fit are already fulfilled, which it prevails for both outer model (Hair, et al., 2017, p. 107) and structural (inner) model (Hair et al., 2017, p. 186). Based on the results of Goodness of Fit test, research model is considered as fit and therefore, hypothesis test can be implemented.

Table 6

Recapitulation of Goodness of Fit Test on All Models

\begin{tabular}{llll}
\hline Goodness of Fit & Parameter & \multicolumn{1}{c}{ Rule of Thumbs } \\
\hline Outer Model & Convergent Validity & Factor Loading & Factor loading of all indicators must be $>0.7 \quad$ Convergent Validity Fulfilled \\
$\begin{array}{l}\text { Discriminant } \\
\text { Validity }\end{array}$ & Cross Loading & $\begin{array}{l}\text { AVE of all indicators must be }>0.5 \\
\text { Factor loading of all indicators in one latent Discriminant Validity Fulfilled } \\
\text { variable must be greater than cross loading of } \\
\text { other latent variable. }\end{array}$
\end{tabular}

\begin{tabular}{|c|c|c|c|c|c|}
\hline & & Reliability & $\begin{array}{l}\text { Composite } \\
\text { Reliability }\end{array}$ & Composite Reliability must be $>0.7$ & Reliable \\
\hline $\begin{array}{l}\text { Structural } \\
\text { Model }\end{array}$ & (Inner) & $R^{2}$ Evaluation & $R^{2}$ Value & $\mathrm{R}^{2}>0.25$ & Model considered as fit \\
\hline
\end{tabular}

(Source: Result of Analysis with Smart-PLS)

\subsection{Results of Hypothesis Test}

Hypothesis test is carried out using bootstrapping method available in computer program of Smart-PLS version 3.2.7. Alternative hypothesis $(\mathrm{Ha})$ is accepted if $\mathrm{t}$-count value $\geq 1.96$ (Hair et al., 2017, p. 186). The recapitulation of results of $t$-test ( $\mathrm{t}$ count) from direct effect test is explained on detail in Table 7.

Table 7.

Summary of t-count results from direct effect test

\begin{tabular}{|c|c|c|c|c|c|c|c|}
\hline \multirow{2}{*}{ No } & \multirow{2}{*}{ Direct Effect } & \multicolumn{2}{|c|}{ Hypothesis } & \multirow{2}{*}{ Path Coeff. } & \multirow{2}{*}{ t-count } & \multirow{2}{*}{ Decision } & \multirow{2}{*}{ Remark } \\
\hline & & $\mathbf{H}_{0}$ & $\mathrm{H}_{\mathrm{a}}$ & & & & \\
\hline 1. & $\begin{array}{l}\mathrm{EO} \text { on } \mathrm{MO} \\
(\mathrm{EO} \rightarrow \mathrm{MO})\end{array}$ & $\mathrm{H}_{0(1)}: \gamma_{11}=0$ & $\mathrm{H}_{\mathrm{a}(1)}: \gamma_{11} \neq 0$ & 0.287345 & 2.046967 & $\begin{array}{c}\mathrm{H}_{0} \text { is rejected, } \mathrm{H}_{\mathrm{a}} \text { is ac- } \\
\text { cepted }\end{array}$ & $\begin{array}{l}\text { The effect is positive and } \\
\text { significant. }\end{array}$ \\
\hline 2. & $\begin{array}{l}\mathrm{TO} \text { on } \mathrm{MO} \\
(\mathrm{TO} \rightarrow \mathrm{MO})\end{array}$ & $\mathrm{H}_{0(2)}: \gamma_{21}=0$ & $\mathrm{H}_{\mathrm{a}(2)}: \gamma_{21} \neq 0$ & 0.431385 & 2.409892 & $\begin{array}{c}\mathrm{H}_{0} \text { is rejected, } \mathrm{H}_{\mathrm{a}} \text { is ac- } \\
\text { cepted }\end{array}$ & $\begin{array}{c}\text { The effect is positive and } \\
\text { significant. }\end{array}$ \\
\hline
\end{tabular}

(Source: Result of Analysis with Smart-PLS Program at significance level ( $\alpha$ ) of 5\%)

As shown in Table 7, both Variable TO and Variable EO have obvious and direct effect on Variable MO. Baron and Kenny's Norm (Hair et al., 2017, p. 222) requires that moderation (mediation) test can only be conducted if the direct effect is significant. In relation with the Norm, it can be said that (1) hypothesis test against moderation effect of Variable E to the influence of Variable TO on Variable MO, can be implemented; and (2) hypothesis test against moderation effect of Variable E to the influence of Variable EO on Variable MO, can be executed. The process of hypothesis test is facilitated by bootstrapping method available in Smart-PLS version 3.2.7. Recapitulation of results of t-statistic ( $\mathrm{t}$-count) from moderation effect test is given in Table 8.

\section{Table 8}

Recapitulation of $\mathrm{t}$-count results from moderation effect test

\begin{tabular}{|c|c|c|c|c|c|c|c|}
\hline \multirow{2}{*}{ No } & \multirow{2}{*}{ Indirect Effect } & \multicolumn{2}{|c|}{ Hypothesis } & \multirow{2}{*}{ Path Coeff. } & \multirow{2}{*}{$\mathrm{t}$-count } & \multirow{2}{*}{ Decision } & \multirow{2}{*}{ Remark } \\
\hline & & $\mathrm{H}_{0}$ & $\mathrm{H}_{\mathrm{a}}$ & & & & \\
\hline 1. & $\begin{array}{c}\text { EO on MO moder- } \\
\text { ated by } \mathrm{E} \\
(\mathrm{EO} * \mathrm{E} \rightarrow \mathrm{MO})\end{array}$ & $\mathrm{H}_{0(3)}: \gamma_{31} * \gamma_{11}=0$ & $\mathrm{H}_{\mathrm{a}(3)}: \gamma_{31} * \gamma_{11} \neq 0$ & 1.284857 & 2.5023 & $\begin{array}{c}\mathrm{H}_{0} \text { is rejected, } \mathrm{H}_{\mathrm{a}} \text { is } \\
\text { accepted }\end{array}$ & $\begin{array}{l}\text { The effect is positive } \\
\text { and significant. }\end{array}$ \\
\hline 2. & $\begin{array}{c}\text { TO on MO moder- } \\
\text { ated by E } \\
\left(\mathrm{TO}^{*} \mathrm{E} \rightarrow \mathrm{MO}\right)\end{array}$ & $\mathrm{H}_{0(4)}: \gamma_{31} * \gamma_{21}=0$ & $\mathrm{H}_{\mathrm{a}(4)}: \gamma_{31} * \gamma_{21} \neq 0$ & -0.862887 & 1.3171 & $\begin{array}{c}\mathrm{H}_{0} \text { is accepted, } \mathrm{H}_{\mathrm{a}} \text { is } \\
\text { rejected }\end{array}$ & $\begin{array}{l}\text { The effect is negative } \\
\text { but not significant. }\end{array}$ \\
\hline
\end{tabular}

(Source: Result of Analysis with Smart-PLS Program at significance level ( $\alpha$ ) of 5\%)

The summary of results of bootstrapping method in determining t-statistic (t-count) is visualized in Fig. 3. 


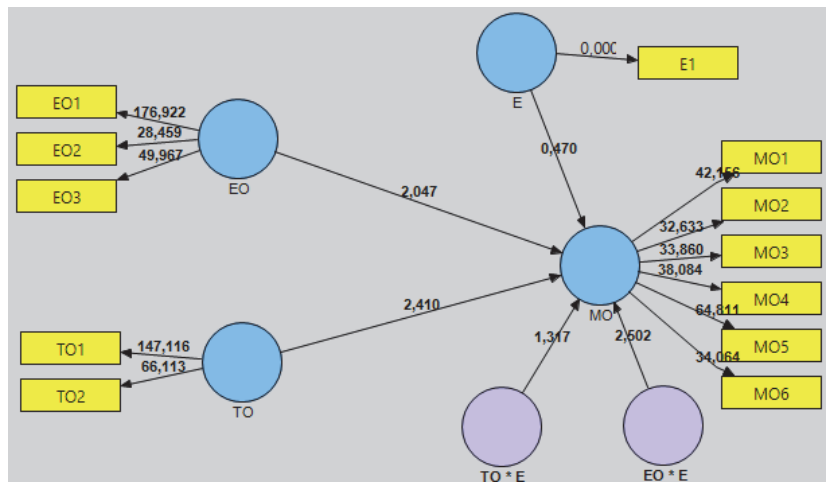

Fig. 3. Hypothesis model

(Source: Result of analysis with Smart-PLS Program at significance level $(\alpha)$ of 5\%)

\section{Discussion}

\subsection{The Influence of Entrepreneurial Orientation on Market Orientation}

Entrepreneurial orientation of the entrepreneurs of Small-and-Medium Enterprises in East Java Province has obvious effect on market orientation. In other words, entrepreneurial orientation can improve market orientation of SMEs and this improvement is statistically significant. Small-and-Medium Enterprises are a kind of business unit and entrepreneurial orientation helps them to get better performance (Cantaleano, Rodrigues, \& Martins, 2018, p. 6). Business units with entrepreneurial orientation tend to be innovative, proactive in capturing opportunity, and dare to take risk (Felgueira \& Rodrigues, 2012, p. 704). Moreover, other element in entrepreneurial orientation is dynamic capability, and this capability enables business units to solve problems that they have identified after detecting opportunities and threats, and responding what market demands in the future (Felgueira \& Rodrigues, 2012, p. 706; Tan, 2016, p. 95). Small-and-Medium Enterprises with greater focus on entrepreneurial orientation are always giving more emphasis on market orientation. Basically, entrepreneurial orientation is absolutely needed by business units to answer the demands of market and entrepreneurs, and also to satisfy customers (Huang \& Wang, 2011, p. 564). Small-and-Medium Enterprises can make strategic plans from the policies related with entrepreneurial orientation and market orientation (Amin, Thurasamy, Aldakhil, \& Kaswuri, 2016, p. 51). If entrepreneurial orientation values are low, the consequence is varying such as lack of innovation, inefficiency, inflexibility, and decision that may reduce market orientation (Idar, Yusoff, \& Mahmood, 2012, p. 69).

\subsection{The Influence of Technology Orientation on Market Orientation}

Empirical finding shows that technology orientation that East Java SMEs entrepreneurs have is positively and significantly affecting market orientation. Therefore, it is then said that technology orientation can improve market orientation of East Java SMEs. One external factor of market orientation is technology (Tomaskova, 2007, p. 82). Consumers tend to choose products that use the latest technology (Ali et al., 2016b, p. 2). Market orientation keeps business units focusing on the use of the latest technology in every business activity (Tomaskova, 2007, p. 82). The use of the latest technology must be comparable to market demand because business units can only survive in the market if their response to new technology is favored by market (Frambach, Fiss, \& Ingenbleek, 2016, p. 1430). Technology capability that business units have can improve their innovation on products (Urban \& Heydenrych, 2015, p. 126). Besides, business units with technology orientation will get competitive advantages after they use their technology, and by this technology, they can offer more innovative products (Ali et al., 2016a, p. 2).

\subsection{The Moderation Effect of Education to the Influence of Entrepreneurial Orientation on Market Orientation}

Empirical finding explains that education does not act as moderation variable to the influence of entrepreneurial orientation on market orientation. Based on this position, it can be said that education does not have negative effect on market orientation, which is probably because East Java SMEs already take entrepreneurial orientation into their consideration. Activeness of SMEs in the market depends on how they compete and grow one another to fulfil market demand that always develops (Frishammar \& Hörte, 2007, p. 765). Small-and-Medium Enterprises can survive longer in business competition if they can translate market demand properly and have strategic orientation to fulfil this demand (Acosta, Crespo, \& Agudo, 2018, p. 1128). If SMEs can apply entrepreneurial values such as innovation, dare to take risk, and aggressive in market competition, then they will have higher market orientation and get their performance increased (Jang1, 2015, p. 166; Rajagopal, 2017, p. 1; Ruzfgar, Kocak, \& Ruzgar, 2014, p. 19). Small-and-Medium Enterprises with high focus on entrepreneurial orientation always do a continuous examination on their products and services. It is done to ensure that consumers will get the best service (Hidayat, Suryana, Afiff, \& Cahyandito, 2016, p. 612). This activity surely needs the capability to understand market shares, and reliable education is a requirement in this point. If SMEs disregard education level and organizational learning in their business units, then they will see the innovation declining, which then put difficulty to them to focus on entrepreneurial orientation, and consequently, it may weaken their market orientation (Amin, 2015, p. 219). 


\subsection{The Moderation Effect of Education to the Influence of Technology Orientation on Market Orientation}

Empirical finding indicates that education is acting as moderation variable in the influence of technology orientation on market orientation. It can be said that education can give negative effect on market orientation of East Java SMEs if technology orientation is taken into account. Low market orientation can produce suboptimal income, which may prevent SMEs from maximizing their technology. Moreover, majority of workers at SMEs have low education level, and therefore, these workers are difficult to apply new technology desired by the market. So far, East Java SMEs suffer from technology limitation due to financial distress (Riwayati, 2017, p. 718). Technology in these SMEs is often unreliable (Munizu et al., 2016, p. 216) and therefore, their technology innovation is not quite promising (Susanto \& Wasito., 2017, p. 282). As consequences, technology orientation is often not considered in Indonesian SMEs' plans, and this clearly defies the fact that technology orientation is one of the most important aspects in production process of business units (Tomaszuk, 2017, p. 701). Previous studies already reported that technology orientation can improve market orientation (Ali et al., 2016a, p. 1; Tomaskova, 2007, p. 81). If the influence of technology orientation is suboptimal, it is possibly associated with low education level of SMEs' workers. Human resource is one factor that determines business units' success, and education is one important attribute of human resource (Nawawi, Husin, \& Wiryawan, 2017, p. 1). Human resource with high education level is considered more able to implement organizational learning (Pantouvakis \& Bouranta, 2013, p. 52), and education becomes very important when workers are required to use new technology (Carruth \& Carruth, 2013, p. 513) and when business units find as necessary to optimize SMEs' performance (Thomas et al., 2017, p. 3). After all, it can be said that high education level among the workers can enable SMEs to attain market orientation.

\section{Conclusion and Suggestion}

Referring to the formulated problems and what this research wants to address, and also pursuant to the empirical findings and the interpretations previously presented, therefore, some conclusions are generated:

1. Entrepreneurial orientation developed by Small-and-Medium Enterprises in East Java has obvious effect on market orientation, precisely that entrepreneurial orientation can improve market orientation.

2. Technology orientation built by Small-and-Medium Enterprises in East Java has obvious and significant effect on market orientation.

3. Education level of SMEs' entrepreneurs strengthens the influence of entrepreneurial orientation on market orientation.

4. Education level can reduce the influence of technology orientation on market orientation, but this reduction is not significant statistically.

The entrepreneurs of SMEs are eager to improve their market orientation, and therefore, it is suggested that:

1. The entrepreneurs of SMEs give more focuses on improving entrepreneurial orientation. It may be started from encouraging workers to be more innovative and to dare to take risk, although these still remain under control and discretion of the manager.

2. Technology orientation can be improved by giving training about the latest technology and the upgrade of the existing technology. This training is early step for SMEs in adapting with the latest market demand.

3. Education level of SMEs' human resource can be improved by ensuring that workers are already highly educated, and also by giving training to the existing workers to obtain the best outcomes, especially training about how to use the latest technology.

\section{References}

Acosta, A. S., Crespo, Á. H., \& Agudo, J. C. (2018). Effect of market orientation, network capability and entrepreneurial orientation on international performance of small and medium enterprises (SMEs). International Business Review, 27(6), 1128-1140.

Ali, L., \& Rehman, R. U. (2016a). The Impact Of Technology Orientation And Customer Orientation On Firm Performance: Evidence Form Chinese Firms.

Ali, R., Leifu, \& Rehman, R. (2016b). The Impact Of Technology Orientation And Customer Orientation On Firm Performance: Evidence Form Chinese Firms. International Journal of Management and Marketing Research, 9(1), 1-11.

Amin, M. (2015). The influence of entrepreneurship orientation and learning orientation on SMEs' performance: an SEM-PLS approach. Journal International Business and Entrepreneurship Development, 8(3), 215-230.

Amin, M., Thurasamy, R., Aldakhil, A. M., \& Kaswuri, A. H. Bin. (2016). The influence of market orientation as a mediating variable in the relationship between entrepreneurial orientation and SMEs performance. Nankai Business Review International, 7(1), 39-59. https://doi.org/10.1108/NBRI-08-2015-0019

Aminu, I. M., \& Shariff, M. N. M. (2014). The relationship between entrepreneurial orientation, market orientation, learning orientation, technology orientation and SMEs performance in Nigeria. In International SME Conference (ISMEC 2014), Kuala Lumpur (pp. 108-116). Retrieved from repo.uum.edu.my

Cantaleano, K. R., Rodrigues, G. P., \& Martins, T. S. (2018). The mediating effect of proactive market orientation capability in entrepreneurial orientation and service innovation. Revista de Administração Mackenzie, 19(1), 1-27.

Carruth, P. J., \& Carruth, A. K. (2013). Educational And Financial Impact Of Technology On Workforce Development. American Journal Of Business Education, 6(5), 513-520.

Dachlan. (2014). Panduan Lengkap Structural Equation Modeling Tingkat Dasar. Semarang: Lentera Ilmu. 
Dachlan, N., Dwiridotjahjono, J., \& Prabowo, B. (2016). Adoption of E-Commerce for Small and Medium Enterprises. The International Journal of Business \& Management, 4(12), 318-326.

Day, G. S. (1998). What does it mean to be market-driven? Business Strategy Review, 9(1), 1-14.

Dursun, T., \& Kilic, C. (2017). Conceptualization and Measurement of Market Orientation: A Review with a Roadmap for Future Research. International Journal of Business and Management, 12(3), 1-18.

Duru, I. U., Ehidiamhen, P. O., \& Chijioke, A. N. J. (2018). Role of Entrepreneurial Orientation in the Performance of Small and Medium Enterprises: Evidence from Federal Capital Territory, Abuja, Nigeria. Asian Journal of Economics, Business and Accounting, 6(1), 1-21.

Felgueira, T., \& Rodrigues, R. G. (2012). Entrepreneurial Orientation, Market Orientation and Performance of Teachers and Researchers in Public Higher Education Institutions. Public Policy and Administration, 11(4), 703-718.

Ferraresi, A. A., Santos, S. A., Frega, J. R., \& Pereira, H. J. (2012). Knowledge Management, Market Orientation, Innovativeness and Organizational Outcomes: a study in companies installed in Brazil. Journal of Information Systems and Technology Management, 9(1), 89-108. https://doi.org/10.4301/S1807-17752012000100005

Frambach, R. T., Fiss, P. C., \& Ingenbleek, P. T. M. (2016). How important is customer orientation for firm performance.pdf. Journal of Business Research, 69(2016), 1428-1436.

Frishammar, J., \& Hörte, S. A. (2007). The Role of Market Orientation and Entrepreneurial Orientation for New Product Development Performance in Manufacturing Firms. Technology Analysis \& Strategic Management Management, 19(6), 765788. https://doi.org/10.1080/09537320701711231

Glavas, A., \& Mish, J. (2015). Resources and Capabilities of Triple Bottom Line Firms: Going Over Old or Breaking New Ground? Journal of Business Ethics, 127(3), 623-642.

Golibjon, Y. (2016). Innovation and SME Development: Indonesian Experience in Uzbekistan Context. Journal of Entrepreneurship \& Organization Management, 5(3), 10-13. https://doi.org/10.4172/2169-026X.1000198

Guzman, M. G., Serna, M. D. C. M., \& Castro, S. Y. P. (2017). Entrepreneurial Orientation and Growth in Mexican Small Business.pdf. Journal of Management and Sustainability, 7(1), 94-102.

Hadiyati, E. (2015). Marketing and Government Policy on MSMEs in Indonesian : A Theoretical Framework and Empirical Study. International Journal of Business and Management, 10(2), 128-141. https://doi.org/10.5539/ijbm.v10n2p128

Hair, J. F., Hult, G. T. M., Ringle, C., \& Sarstedt, M. (2017). A primer on partial least squares structural equation modeling (PLSSEM). SAGE Publications.

Hidayat, C., Suryana, Y., Afiff, F., \& Cahyandito, M. F. (2016). The Relationship of Entrepreneurial and Market Orientation , Marketing Mix ,. International Journal of Economics, Commerce and Management, IV(9), 611-622.

Hosseininia, G., \& Ramezani, A. (2016). Factors Influencing Sustainable Entrepreneurship in Small and Medium-Sized Enterprises in Iran: A Case Study of Food Industry. Sustainability, 8(10), 1010. https://doi.org/10.3390/su8101010

Huang, S. K., \& Wang, Y. L. (2011). Entrepreneurial orientation, learning orientation, and innovation in small and medium enterprises.pdf. Procedia - Social and Behavioral Sciences, 24(2011), 563-570.

Hussain, J., Rahman, W., \& Shah, F. A. (2016). Market Orientation and Performance: The Interaction Effect of Entrepreneurial Orientation. Pakistan Journal of Commerce and Social Sciences, 10(2), 388-403.

Idar, R., Yusoff, Y., \& Mahmood, R. (2012). The influence of Market Orientation as Mediator to strategic planning Practices and Performance Relationship, Evidence from Malaysian SMEs. Procedia Economics and Finance, 4(2012), 68-75.

Jangl, P. (2015). Relationship Between Market Orientation And Business Performance In Czech And German High-Tech Firms. Market-Tržište, 27(2), 153-170.

Jaya, I. G. N. M., \& Sumertajaya, I. M. (2008). Pemodelan Persamaan Struktural dengan Partial Least Square. In Seminar Nasional Matematika dan Pendidikan Matematika 2008 Jurusan Pendidikan Matematika FMIPA Universitas Negeri Yogyakarta. Yogyakarta.

Jogiyanto. (2011). Konsep dan Aplikasi Structural Equation Modelling (SEM) Berbasis Varian dalam Penelitian Bisnis. Yogyakarta: Unit Penerbit dan Percetakan STIM YKPN Yogyakarta.

Kalmuk, G., \& Acar, A. Z. (2015). The Mediating Role of Organizational Learning Capability On The Relationship Between Innovation and Firm's Performance: A Conceptual Framework. Procedia - Social and Behavioral Sciences, $210(1), 164$ - 169.

Kasim, A., \& Altinay, L. (2016). How do Technology Orientation, Organizational Learning, Market Conditions, and firm Growth Connect? A Preliminary Analysis on Small and Medium Size Hotels in Peninsular Malaysia. International Review of Management and Marketing, 6(S7), 121-126.

Kiessling, T., Isaksson, L., \& Yasar, B. (2016). Market Orientation and CSR: Performance Implications. Journal of Business Ethics, $137(2), 269-284$.

Kim, J. (2017). Learning 2.0 in Knowledge Economy: A Case Study of a Pilot Project in Zambia. International Journal of Regional Development, 4(2), 42-63. https://doi.org/10.5296/ijrd.v4i2.11110

Kohli, A. K., \& Jawarski, B. J. (1990). Market Orientation: The Construct, Research Propositions and Management Implication. Journal of Marketing, 54.

Kozubíková, L., Sopková, G., Krajčík, V., \& Tyll, L. (2017). Differences in innovativeness, proactiveness and competitive aggressiveness in relation to entrepreneurial motives. Journal of International Studies, 10(4), 207-218.

Lo, M. C., Wang, Y. C., Wah, C. R. J., \& Ramayah, T. (2016). The critical success factors for organizational performance of SMEs in Malaysia: a partial least squares approach. Review of Business Management, 18(61), 370-391.

Malhotra, N. K., Nunan, D., \& Birks, D. F. (2017). Marketing Research An Applied Approach Fifth Edition. Harlow: Pearson.

Munizu, M., Sumardi, \& Armayah. (2016). Study on Determinant Factors of Micro and Small Enterprises Development in South Sulawesi of Indonesia. https://doi.org/10.5901/mjss.2016.v7n6p121

Nakola, J. O., Tarus, B. K., Buigut, K., \& Kipchirchir, K. E. (2015). Effect Of Strategic Orientation On Performance Of Small And Medium Enterprises: Evidence From Kenya. International Journal of Economics, Commerce and Management, 3(11), 336-351. 
Nawawi, T., Husin, R., \& Wiryawan, Z. Z. (2017). Business and Economics Profile and Marketing Strategy of SME's Towards Jambi Batik, 8(4), 4-9. https://doi.org/10.4172/2151-6219.1000

Neneh, B. N., \& Zyl, J. V. (2017). Entrepreneurial orientation and its impact on firm growth amongst SMEs in South Africa. Problems and Perspectives in Management, 15(3), 166-178.

Omsa, S., Ridwan, M., \& Jayadi, M. (2017). The influence of Strategic Management Practices on SME Performances in Makassar, Indonesia. American Journal of Theoretical and Applied Business, 3(4), 71-78.

Othman, N. H., Pazil, A. H. M., Attaullah, S. A., Zaib, S. Z. M., Jin, C. W., \& Mahadi, N. F. D. (2016). Influence of Work Experience and Education towards Business Performance among Entrepreneurs. International Business Education Journal, 9(1), $78-87$.

Pantouvakis, A., \& Bouranta, N. (2013). The link between organizational learning culture and customer satisfaction. The Learning Organization, 20(1), 48-64.

Platin, N., \& Ergun, H. S. (2017). The Relationship between Entrepreneurial Orientation and Performance; Evidence from Turkish SMEs. Business and Management Studies, 3(2), 78-89.

Protcko, E., \& Dornberger, U. (2014). The impact of market orientation on business performance - the case of Tatarstan knowledgeintensive companies ( Russia ). Problems and Perspectives in Management, 12(4), 225-231.

Rahadi, R. A. (2016). Opportunities And Challenges For Micro-Small And Medium Business In Indonesia Facing Asean Economic Community. Jurnal Manajemen Dan Kewirausahaan, 18(1), 45-53.

Rajagopal, R. (2017). The Mediating Effect of Organizational Learning Capability on High Performance Work System and Corporate Enterpreneurship Relationship. In International Conference on Literature, History, Humanities and Social Sciences.

Rekarti, E., \& Doktoralina, C. M. (2017). Improving Business Performance: A Proposed Model for SMEs. European Research Studies Journal, 20(3), 613-623.

Riwayati, H. E. (2017). Analysis Banking Role to Performance Improvement on Indonesia Small Medium Enterprises. European Research Studies Journal, 20(3A), 717-728.

Rupčić, N. (2016). Exploring Strategic and Learning Orientation: Is There Room for Controversy? In Proceedings of the 8th International Conference "An Enterprise Odyssey: Saving the sinking ship through human capital” (pp. 245-253).

Ruzfgar, N. S., Kocak, A., \& Ruzgar, B. (2014). The Mediating Effect of Market Orientation on the Relationship between Entrepreneurial Orientation and Performance. In Recent Advances in Financial Planning and Product Development.

Sanjo, M. O., \& Ibrahim, M. O. (2017). The influence of International Business on SMEs Growth in Nigeria. Journal of Competitiveness, 9(3), 67-80. https://doi.org/10.7441/joc.2017.03.05

Segarra-Ona, M. V., Peiro-Signes, A., \& Cervello-Royo, R. (2015). A Framework to Move Forward on the Path to Eco-innovation in the Construction Industry: Implications to Improve Firms' Sustainable Orientation. Science and Engineering Ethics, 21(6), $1469-1484$.

Sidik, I. G. (2012). Conceptual framework of factors affecting SME development Mediating factors on the relationship of entrepreneur traits and SME performance. Procedia Economics and Finance, 4(2012), 373-383.

Slater, S. F., \& Narver, J. C. (1995). Market Orientation and the Learning Organizational. Journal of Marketing, 59.

Sudaryo, Y., \& Permatasari, D. (2017). Strategy Development Micro Small And Medium Business Performance In Small And Medium Enerprises (Smes) Cibduyut Shoe Bandung. International Journal of Scientific \& Technology Research, 6(3), $102-105$.

Susanto, A. B., \& Wasito. (2017). Improve The Performance Of SMES Through Innovation Strategies In Developing Countries. International Journal Of Scientific \& Technology Research, 6(10), 282-285.

Tambunan, T. T. H. (2017). Women Entrepreneurs in MSEs in Indonesia: Their Motivations and Main Constraints. International Journal of Gender and Women's Studies, 5(1), 88-100. https://doi.org/10.15640/ijgws.v5n1p9

Tan, J. (2016). The Performance of Entrepreneurially Oriented Organisations. Otago Management Graduate Review, 14(2016), 93101.

Thomas, A., Dorrington, P., Costa, F., Loudon, G., Francis, M., \& Fisher, R. (2017). Organisational learning capability in SMEs.pdf. Cogent Business \& Management, 4(2017), 1-20.

Tomaskova, E. (2007). The Current Models of Market Orientation. European Research Studies, XI(3-4), 81-88.

Tomaszuk. (2017). Importance of Technological Factors in the Creation of Cooperation. Procedia Engineering, 182(2017), 701708.

Urban, B., \& Heydenrych, J. (2015). Technology Orientation And Effectuation - Links To Firm Performance In The Renewable Energy Sector Of South Africa. South African Journal of Industrial Engineering November, 26(3), 125-136.

Wilson, G. A., Perepelkin, J., Zhang, D. D., \& Vachon, M. A. (2014). Market Orientation, Alliance Orientation, And Business Performance In The Biotechnology Industry. Journal of Commercial Biotechnology, 20(2), 32-40.

Zainul, M., Astuti, E. S., Arifin, Z., \& Utami, H. N. (2016). The influence of Market Orientation toward Organizational Learning, Innovation, Competitive Advantage, and Corporate Performance. Journal of Administrative Sciences and Policy Studies, 4(1), $1-19$.

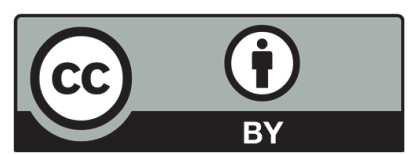

(C) 2020 by the authors; licensee Growing Science, Canada. This is an open access article distributed under the terms and conditions of the Creative Commons Attribution (CC-BY) license (http://creativecommons.org/licenses/by/4.0/). 